\title{
Impact of continental meteorology and atmospheric circulation in the modulation of Aerosol Optical Depth over the Arabian Sea
}

\author{
SANDhYA K NAIR*, S SiJIKUMAR and S S PRIJITH \\ Space Physics Laboratory, Vikram Sarabhai Space Centre, Indian Space Research Organization, \\ Thiruvananthapuram 695 022, Kerala, India. \\ *Corresponding author.e-mail: sandymad@gmail.com
}

\begin{abstract}
Time series analysis of Aerosol Optical Depth (AOD) derived from NOAA-AVHRR data during the period 1996-1999 and the MODIS data during 2000-2009 over the Arabian Sea revealed a systematic biennial variability in the high AOD during summer months. The variability is more prominent over the northern and central parts of the Arabian Sea and became less significant towards southern latitudes. The possible mechanisms for these are examined by estimating the source strength over coastal Arabia and AOD flow rate through the western boundary of the Arabian Sea. Both these show clear signatures of biennial variability with same phase as AOD for most of the years. This result indicates that the observed biennial variability in AOD is likely to be the outcome of combined effects of biennial variability in wind generated sea-salt aerosols and dust transported from Arabia.
\end{abstract}

\section{Introduction}

Atmospheric aerosols play a vital role in the climate system and the hydrological cycle (Charlson et al 1992; Ramanathan et al 2001; IPCC 2007). They interact directly with solar and thermal radiation through scattering and in some cases by absorbing the solar radiation. Thus, aerosols can cool the surface while warming the atmosphere leading to changes in atmospheric thermodynamics, stability, hydrological cycle and cloud development (Twomey et al 1984; Charlson et al 1992; Satheesh and Ramanathan 2000; Ramanathan et al 2001). Aerosols can also interact with clouds by acting as cloud condensation nuclei, increasing the number and reducing the cloud droplet size, thus affecting the cloud albedo which influences the precipitation pattern, cloud cover and possibly the frequency of extreme events (Rosenfeld 1999, 2000; Andreae et al 2004; Kaufman and Koren 2006).

Unlike greenhouse gases, which possess long lifetime and a near-homogeneous spatial distribution, atmospheric aerosols are highly heterogeneous and have the lifetime of the order of one week in the lower troposphere. The spatial distribution of aerosols over a source region thus strongly depends on the source/sink strength and the background atmospheric condition. This necessitates continuous monitoring of aerosols on regional and global scale. Several authors have documented the regional and global distribution of aerosols and their variability over the oceanic regions and also over the land surface using long-term satellite data (Husar et al 1997; Rajeev et al 2000; Nair et al 2003, 2005b). Regional distribution of aerosols, their inter-annual variabilities, and the spectral

Keywords. Atmospheric aerosols; satellite remote sensing; Indian Ocean. 
optical depths are essential inputs to regional and global aerosol models to assess regional radiative forcing and climatic impacts (Saha et al 2005).

In recent years, there have been studies on the role of natural atmospheric motions like planetary waves and oscillations in producing significant changes in the Aerosol Optical Depth (AOD). Beegum et al (2009) have reported Quasi Biennial Oscillation (QBO) on the monthly mean spectral AOD from four locations over Asia and Africa. They found that the QBO in AOD is well associated with the QBO in the stratospheric zonal wind. Using AOD spectra over several sites in peninsular India during the winter season of 19962003, Saha et al (2005) have observed enhancements from the climatological mean, nearly every alternate year, with varying magnitudes and have attributed it primarily to the large scale atmospheric dynamics. Nair et al (2005b) have examined the inter-annual variability of AOD over the oceanic region around the Indian subcontinent using AVHRR-derived AOD during the period 1996-2003. It is reported that the interannual variability in AOD over the Arabian Sea is more prominent during summer-monsoon season (June-September) especially during the month of July.

In the present study, we examine the enhancement of summer peak in AOD in alternate years over the Arabian Sea and its association with prevailing meteorological conditions using continuous and long-term database of 14 years. Moreover, the possible reason for the biennial variability in AOD is also examined using AOD and wind data.

\section{Data}

The basic data used for the present study are the monthly mean AOD during the period 1996-2009, derived from two satellite sensors; (1) Advanced Very High Resolution Radiometer (AVHRR/2) onboard NOAA-14/16 and (2) Moderate Resolution Imaging Spectro-radiometer (MODIS) onboard AQUA/TERRA. Due to the delay in the equatorial crossing time of NOAA-14, the solar zenith angle for most of the pixels was very high in the anti-solar side of the scan during the year 2000. This leads to a larger uncertainty in the derived AOD values. The NOAA-16 data is available only from March 2001. This has resulted in a data gap of 14 months, from January 2000 to February 2001. The AOD data from MODIS is available only from the year 2000. Hence we have used NOAA-14 data only up to December 1999 and MODIS derived AOD values from 2000 onwards. These two together constitute a long term AOD data of 14 years for the present analysis. An inter-comparison of monthly mean AOD values from MODIS and AVHRR was carried out during the same common observation period of 2001-2003. Comparison of the observations shows good agreement between these two satellite-derived AOD values with a correlation coefficient of 0.889 . For the period 1996-1999, the monthly mean AOD is derived from the measured upwelling radiance in channel 1 of NOAA-AVHRR sensor at $630 \pm 50 \mathrm{~nm}$. The method of deriving AOD is described in detail in earlier publications (Rajeev et al 2000; Nair et al 2003, 2005b). The AOD data only from clear sky pixels are identified employing appropriate cloud screening (Rajeev and Ramanathan 2001) and data only from those pixels are used in this study. They are identified by employing appropriate cloud screening and has a spatial resolution of $5 \mathrm{~km}$ at nadir (in Global Area Coverage format). This basic data is further grouped and averaged at appropriate grids and time-scales for studying different aspects.

The MODIS sensor onboard the satellites Terra (10:30 am, equatorial crossing time) and Aqua (1:30 pm, equatorial crossing time) of NASA retrieves total column AOD from near-global daily observations. Over the oceanic region, MODIS used calibrated radiances observed in six wavelength bands $0.55,0.66,0.87,1.24,1.64$ and $2.13 \mu \mathrm{m}$ at a spatial resolution of 0.5 and $0.25 \mathrm{~km}$ under clear sky conditions identified by a cloud-masking algorithm (Martins et al 2002) to retrieve aerosol properties (Levy et al 2003; Remer et al 2005). The MODIS retrieved AOD values over the ocean has an accuracy of \pm 0.03 (Levy et al 2003, 2005; Remer et al 2002, 2005). The MODIS AOD used for the present study are the L3 MOD08 data product, version 4 reported at $0.55 \mu \mathrm{m}$, on $1^{\circ} \times 1^{\circ}$ spatial grids. The AOD obtained from MODIS is at $550 \mathrm{~nm}$ and AVHRR is at $630 \mathrm{~nm}$. The MODIS AOD at $550 \mathrm{~nm}$ is adjusted to $630 \mathrm{~nm}$ using the corresponding values of Angstrom exponent $(\alpha)$ based on MODIS observation reported by Parameswaran et al (2008). The mean values of $\alpha$ reported during the Asian dry season (NovemberApril) is $0.8 \pm 0.2$ and summer monsoon season (June-September) is $0.4 \pm 0.15$. The values of $\alpha$ used for the present investigations are in agreement with other reported values over the study region (Satheesh and Moorthy 1997; Satheesh et al 2002; Vinoj and Satheesh 2003; Babu et al 2008). The value of Angstrom exponent used for the present study can create maximum uncertainty of $11 \%$ in the AOD during the Asian dry season and 9\% during summer monsoon season. Meteorological features for the present study were obtained from NCEP/NCAR reanalysis (Kalnay et al 1996) data 
provided by the NOAA-CIRES Climate Diagnostics Center, Boulder, Colorado which is available on their website at http://www.cdc.noaa.gov.

\section{Results}

Figure 1(a) shows the eight grid boxes covering northern Arabian Sea (NAS), central Arabian Sea (CAS) and southern Arabian Sea (SAS), selected for the time series analysis of AOD. The locations selected for the time series analysis are (NAS: $20^{\circ}-25^{\circ} \mathrm{N} ; 60^{\circ}-65^{\circ} \mathrm{E}, \mathrm{CAS}(1): 15^{\circ}-20^{\circ} \mathrm{N} ; 58^{\circ}-63^{\circ} \mathrm{E}$, $\mathrm{CAS}(2): 15^{\circ}-20^{\circ} \mathrm{N} ; 63^{\circ}-68^{\circ} \mathrm{E}, \operatorname{CAS}(3): 15^{\circ}-20^{\circ} \mathrm{N}$; $68^{\circ}-73^{\circ} \mathrm{E}, \operatorname{SAS}(1): 10^{\circ}-15^{\circ} \mathrm{N}, 55^{\circ}-60^{\circ} \mathrm{E}, \operatorname{SAS}(2)$ : $10^{\circ}-15^{\circ} \mathrm{N} ; 60^{\circ}-65^{\circ} \mathrm{E}, \operatorname{SAS}(3): 10^{\circ}-15^{\circ} \mathrm{N} ; 65^{\circ}-70^{\circ} \mathrm{E}$, and $\operatorname{SAS}(4)$ : $\left.10^{\circ}-15^{\circ} \mathrm{N} ; 70^{\circ}-75^{\circ} \mathrm{E}\right)$. Figure $1(\mathrm{~b})$ shows the temporal variation of the AOD (constructed as discussed in section 2) over different grid locations over the Arabian Sea. All the locations revealed high AODs during the summer monsoon period especially during July and a minimum during the winter/pre-monsoon period. These annual variations in AOD are associated with the changes in the atmospheric circulation and precipitation over this region (Nair et al 2005b; Moorthy et al 2007). During the summer monsoon season the prevailing wind over the Indian subcontinent, over SAS and CAS is predominantly southwesterly while it is predominantly northwesterly over NAS. The extreme high AOD over the Arabian Sea is contributed significantly by the dust aerosols originated at the peninsular Arabia, which are transported by the strong north-westerly offshore wind (Satheesh and Srinivasan 2002; Nair et al 2005b; Saha et al 2005). The high wind speed associated with the monsoonal circulation also produces significant amount of sea-salt aerosols over the Arabian Sea. These aspects have been discussed earlier (Nair et al 2003, 2005b; Moorthy et al 2005, 2007; Gogoi et al 2009) and hence, not detailed here. However, the quite interesting aspect emerging from figure $1(\mathrm{~b})$ is the significant amplification in this AOD peak every alternate year (as indicated by down pointing arrows in figure), which is most clearly discernible in the NAS and CAS grid boxes, and is weakly reflected over other grids as if a major source region is situated over Arabia.

Wavelet analysis has been carried out to delineate dominant periodicities in AOD using a Morlet Wavelet (Torrence and Compo 1998). The wavelet transforms generate an amplitude spectrum of the time series data in time and frequency domain. By decomposing the time series into time-frequency space, one is able to determine both the dominant modes of variability and how those modes vary in time. The time series of AOD over CAS $\left(15^{\circ}-20^{\circ} \mathrm{N} ; 58^{\circ}-63^{\circ} \mathrm{E}\right)$ and the wavelet corresponding to time series are shown in figure 2 ('cone of influence' is shaded). The preliminary observation of the wavelet spectra reveals the presence of quasi-biennial periodicity of $\sim 24-28$ months with an amplitude ranging from -0.3 to 0.3 .

Aerosol variability over the oceanic regions is strongly coupled with the variability in the lower tropospheric circulation. Influence of low level wind variability in the near surface aerosols over the oceanic regions was reported by several authors (Smirnov et al 2000; Chapman et al 2002). Extensive measurements of sea-salt aerosols and seasalt AOD over oceanic regions have revealed that the concentration of sea-salt aerosols depends strongly on local wind speed near the sea surface and the AOD generation increases exponentially with increase in wind speed (Moorthy et al 1997; Moorthy and Satheesh 2000; Nair et al 2005a; Satheesh et al 2006; Parameswaran et al 2008). In addition, dust transport from the Arabia also contributes significantly to the high values of AOD over the Arabian Sea observed during summer monsoon season (Nair et al 2005b). So it is quite reasonable to conjecture that the observed biennial variability in AOD over the CAS could either be contributed by the variation in sea-salt abundance produced by the high winds associated with the monsoonal circulation or due to the advected dust from the Arabia or both. Figure 3 shows the time series plot of AOD and $10 \mathrm{~m}$ wind from QuikSCAT over CAS during the period 1996-2009. It is observed that both the AOD and surface wind show significant peak during the July month in all the years of observation, which is in agreement with the earlier studies (Parameswaran et al 2008). Moreover, presence of biennial variability is clearly seen in the surface wind over the Arabian Sea.

The next significant contributor towards the AOD over the Arabian Sea during the summer monsoon period is the mineral dust transported from the Arabia (Nair et al 2005b; Zhu et al 2007). Figure 4(a, b) shows the temporal variation of AOD over the Arabian Sea and zonal and meridional components of wind at four vertical levels $1000,850,700$ and $500 \mathrm{hPa}$ over Arabia $\left(18^{\circ}-25^{\circ} \mathrm{N}\right.$; $40^{\circ}-55^{\circ} \mathrm{E}$ ) for the month of July during $1996-2009$. The biennial variability in AOD over CAS is clearly matching with the variability in zonal wind over Arabia below $500 \mathrm{hPa}$ level, whereas signatures are not clear in the meridional wind. Earlier studies have reported that during the summer monsoon season the dust aerosol over Arabian Sea is mainly transported from Arabia through wind above surface level (Nair et al 2005b). To delineate the periodicities in wind over Arabia, wavelet analysis has been carried out at $850 \mathrm{hPa}$ zonal wind averaged over the region $\left(20^{\circ}-30^{\circ} \mathrm{N} ; 40^{\circ}-55^{\circ} \mathrm{E}\right)$ during the 


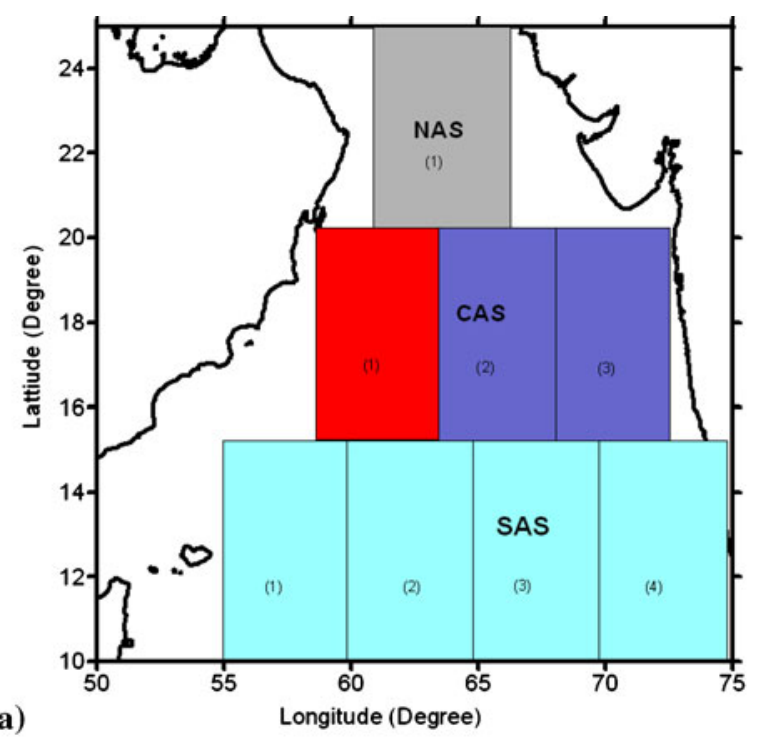

NAS: Northern Arabian Sea CAS: Central Arabian Sea SAS: Southern Arabian Sea

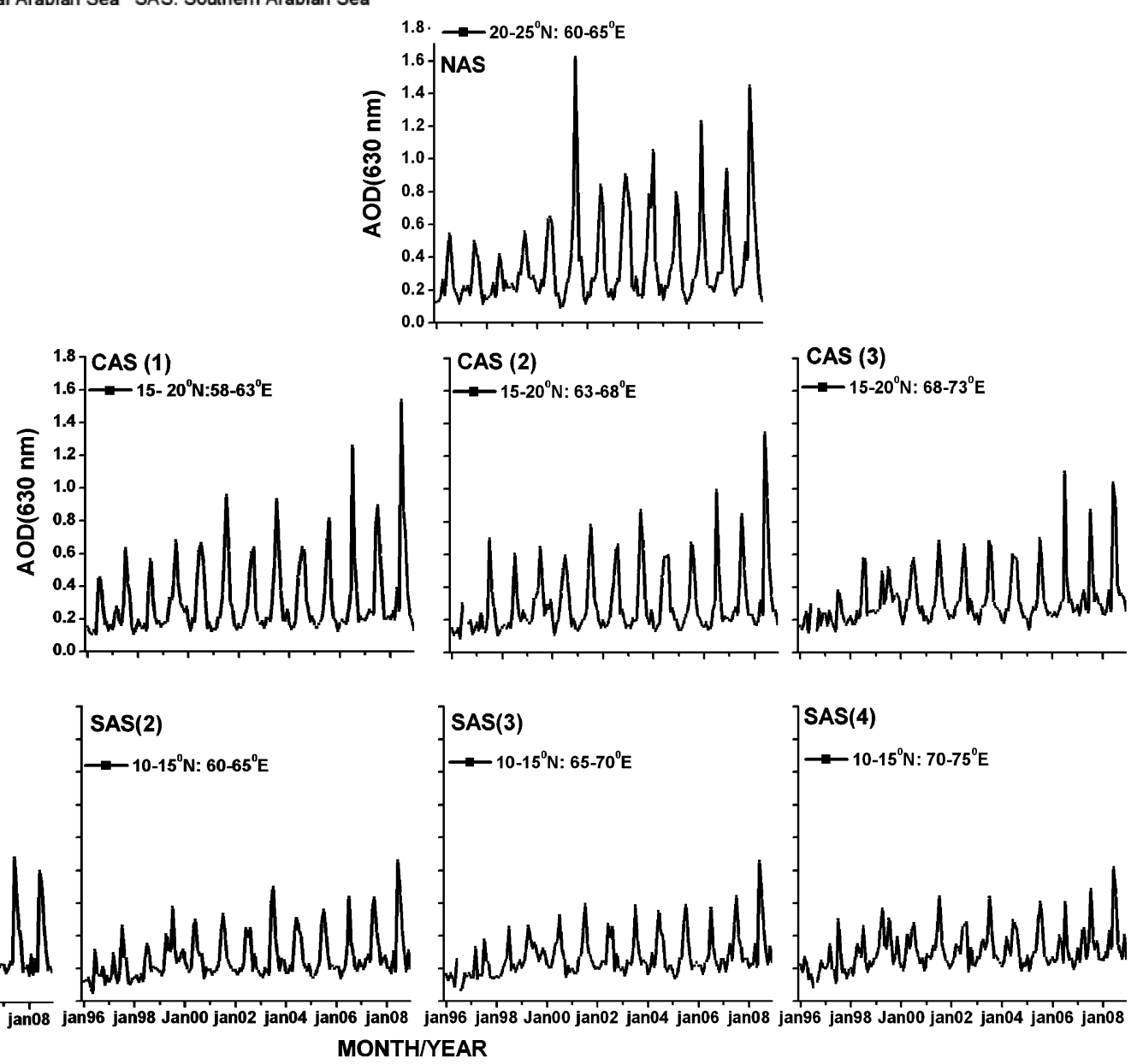

(b)

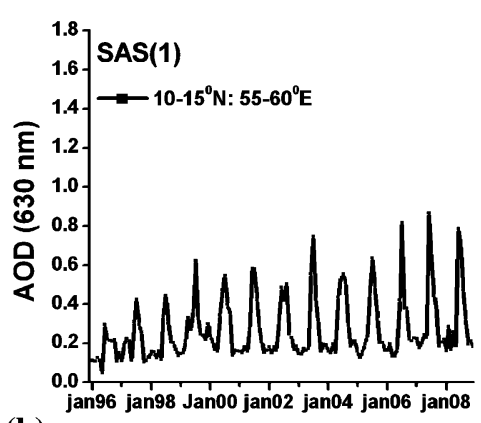

)
MONTH/YEAR

Figure 1. (a) Illustration of the grid boxes selected for the present study. (b) Time series plot of the AVHRR and MODIS derived AOD at different locations over the Arabian Sea [NAS: $20^{\circ}-25^{\circ} \mathrm{N} ; 60^{\circ}-65^{\circ} \mathrm{E}, \mathrm{CAS}(1): 15^{\circ}-20^{\circ} \mathrm{N} ; 58^{\circ}-63^{\circ} \mathrm{E}, \mathrm{CAS}(2)$ : $15^{\circ}-20^{\circ} \mathrm{N} ; 63^{\circ}-68^{\circ} \mathrm{E}, \operatorname{CAS}(3): 15^{\circ}-20^{\circ} \mathrm{N} ; 68^{\circ}-73^{\circ} \mathrm{E}, \operatorname{SAS}(1): 10^{\circ}-15^{\circ} \mathrm{N} ; 55^{\circ}-60^{\circ} \mathrm{E}, \operatorname{SAS}(2): 10^{\circ}-15^{\circ} \mathrm{N} ; 60^{\circ}-65^{\circ} \mathrm{E}, \mathrm{SAS}^{\circ}(3)$ : $\left.10^{\circ}-15^{\circ} \mathrm{N} ; 65^{\circ}-70^{\circ} \mathrm{E}, \operatorname{SAS}(4): 10^{\circ}-15^{\circ} \mathrm{N} ; 70^{\circ}-75^{\circ} \mathrm{E}\right]$ after adjusting for the wavelength difference.

period 1996-2009 and is subject to wavelet analysis. The amplitude of the wavelet spectra is shown in figure 5. Strong signals of biennial periodicities are persisted in the zonal wind with considerable amplitudes which are in phase with the periodicities in AOD. In other words, stronger the wind 


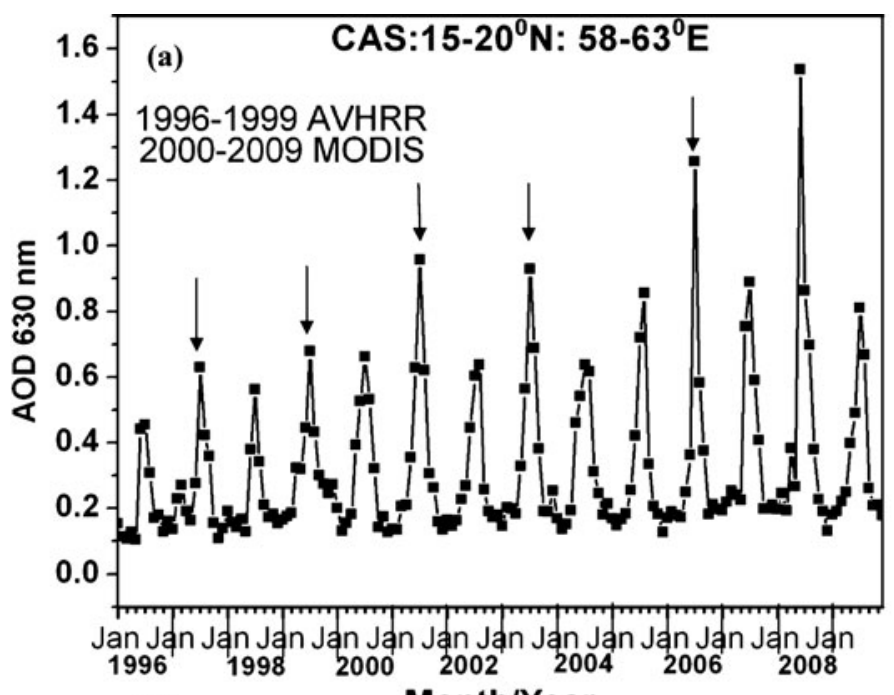

(b)

Month/Year

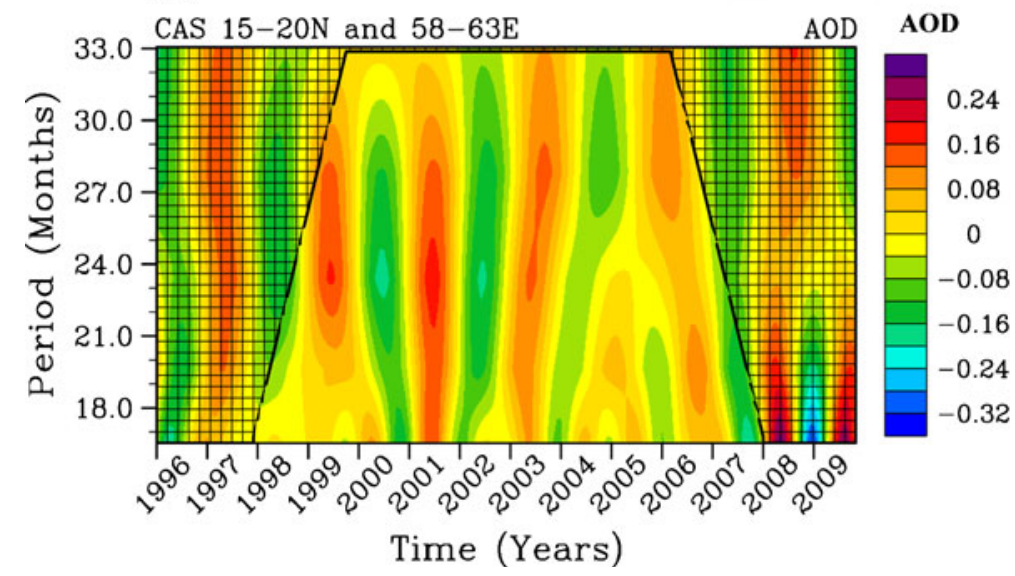

Figure 2. Time series of AOD over coastal Arabia $\left[15^{\circ}-20^{\circ} \mathrm{N} ; 58^{\circ}-63^{\circ} \mathrm{E}\right]$ (a) and wavelet spectra (b) during the period 1996-2009. The colour scheme represents the amplitude of AOD.

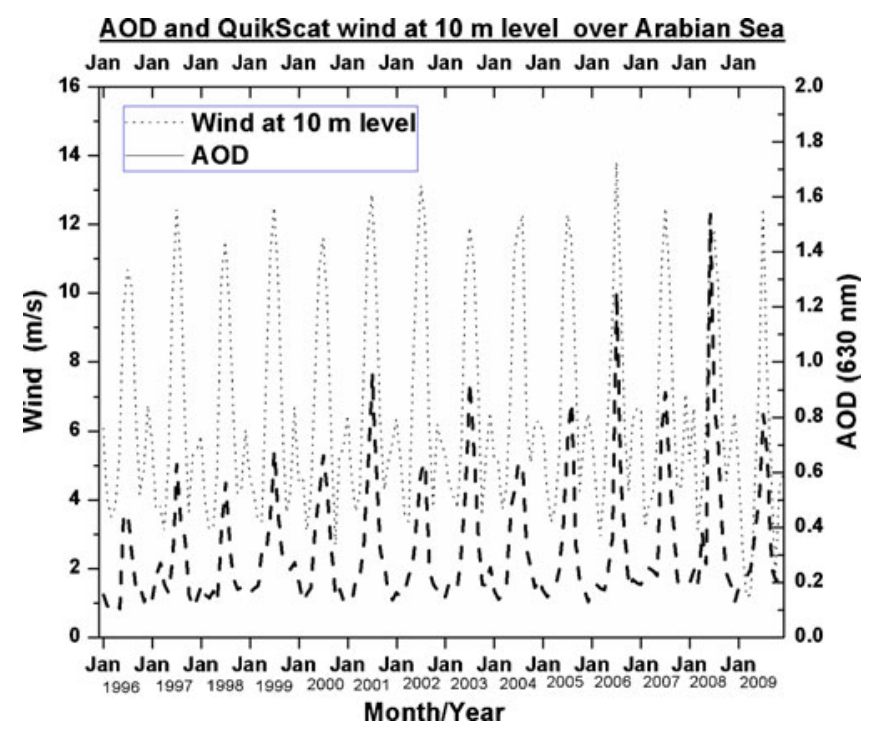

Figure 3. Time series of AOD and wind at $10 \mathrm{~m}$ level from QuikSCAT over the coastal Arabia $\left[15^{\circ}-20^{\circ} \mathrm{N} ; 58^{\circ}-63^{\circ} \mathrm{E}\right]$ during the period 1996 to 2009. over Arabia, higher the AOD over the Arabian Sea and vice versa. This shows that the observed biennial variability in AOD may also be contributed by the lower tropospheric circulations over the source regions.

In order to ascertain the possible mechanism for the observed biennial variability in AOD over the CAS, a more quantitative approach has been examined using the AOD values and wind. The quantities aerosol source/sink strength (S) and AOD Flow Rate (AFR) are estimated to check the causative mechanism for the observed variability in AOD. Aerosol source strength is estimated using aerosol flux continuity described through equation (1) (Aloysius et al 2008).

$$
\frac{\partial \rho}{\partial t}+\nabla \cdot[\rho v]=s_{0}
$$

all of which are in general, functions of the spatial coordinates (i.e., $x, y$ and $z$, respectively) and time $(t)$ where $\rho$ is the aerosol extinction coefficient per unit volume, $v$ is the three dimensional vector wind 


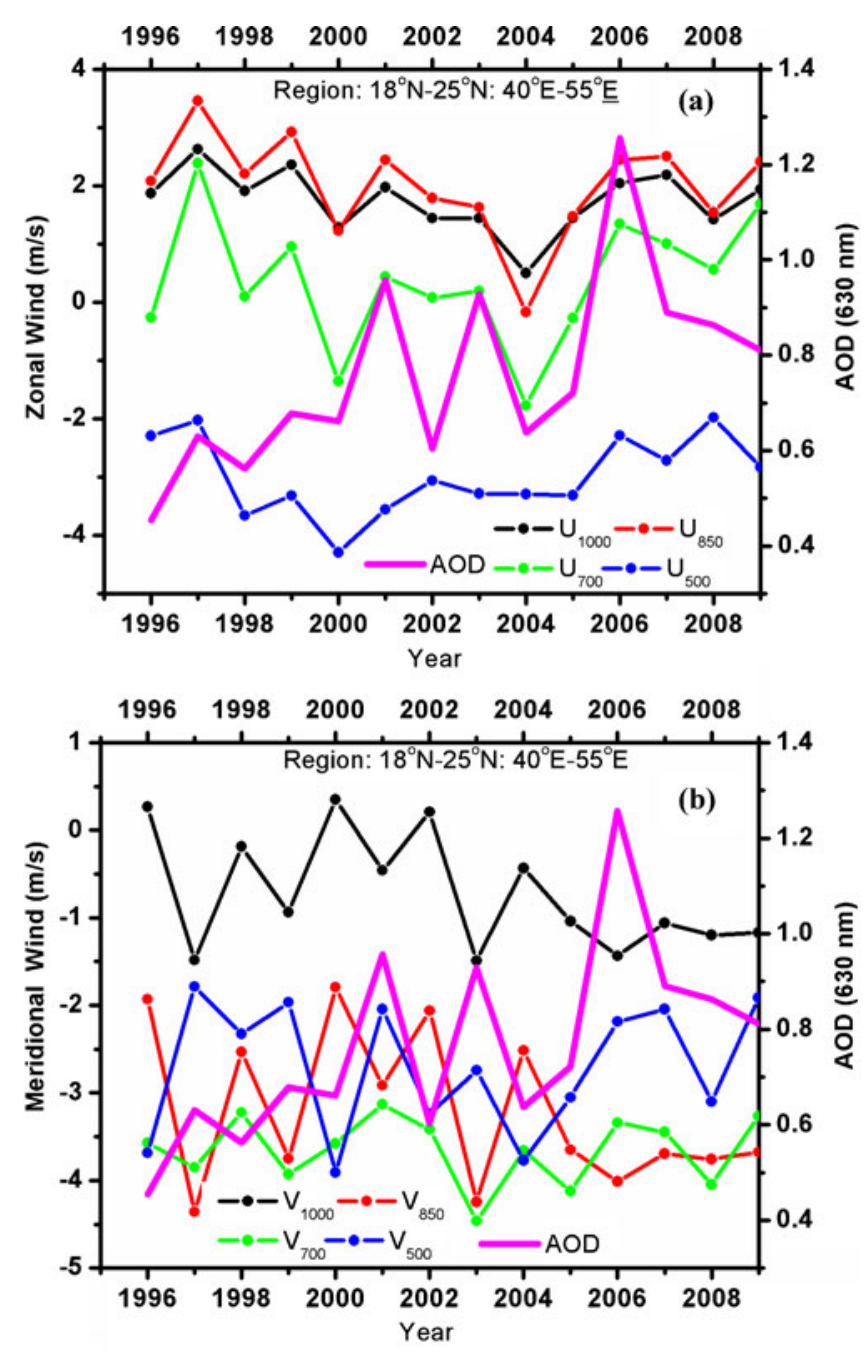

Figure 4. (a) Variation of AOD over coastal Arabia and zonal wind at different altitude levels (1000, 850, 700 and $500 \mathrm{hPa}$ ) over Arabia for the month of July during the period 1996-2009 and (b) same as figure (a) but for meridional wind. and $s_{0}$ is the net source representing dry/wet deposition, production, etc., all of which are in general, functions of spatial coordinates (i.e., $x, y$ and $z$, respectively) and time $(t)$. The columnar aerosol optical depth $(\tau)$ is then defined as:

$$
\tau(x, y)=\int_{0}^{\infty} \rho(x, y, z) d z .
$$

Integrating equation (1) over $z$ results in,

$$
\frac{\partial \tau}{\partial t}+\frac{\partial}{\partial x}\left[\int_{0}^{\infty} \rho u d z\right]+\frac{\partial}{\partial y}\left[\int_{0}^{\infty} \rho v d z\right]=S(x, y, t),
$$

where $u, v$ and $S$ are the zonal wind, meridional wind and column integrated net source, respectively. Daily AOD from MODIS and zonal and meridional winds from NCEP/NCAR reanalysis is used for the computation of $S$. Since NCEP/NCAR wind are available at $2.5^{\circ} \times 2.5^{\circ}$ grid resolution, the $1^{\circ} \times 1^{\circ}$ MODIS AOD data were adjusted to NCEP/NCAR reanalysis grid.

The second quantity estimated here is the AFR. AFR is the product of aerosol optical depth and wind velocity. It means that AFR increases with increase in AOD or wind speed or both. It quantifies the rate of flow of aerosols across the defined boundary and is not expressed in terms of mass or number concentration of aerosols. AFR estimated through the western boundary of the Arabian Sea is shown in figure 6(a) (by the arrow). The AFR is estimated by integrating aerosol extinction at a particular column and the corresponding wind component across the boundary (either zonal or meridional) of the region of interest. The AOD from MODIS is distributed vertically in each pixel as layerwise extinction corresponds to standard pressure levels using an exponentially decreasing function by assuming a scale height of $2 \mathrm{~km}$. The

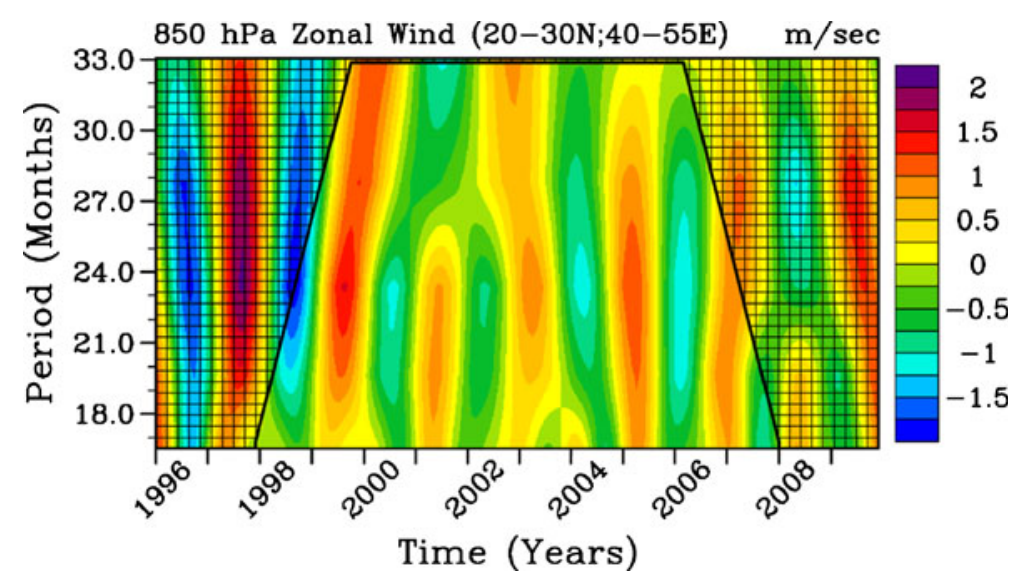

Figure 5. Wavelet analysis of zonal wind at $850 \mathrm{hPa}$ level over Arabia $\left[20^{\circ}-30^{\circ} \mathrm{N} ; 40^{\circ}-55^{\circ} \mathrm{E}\right]$ during the period $1996-2009$. The colour scheme represents the amplitude of wind. 

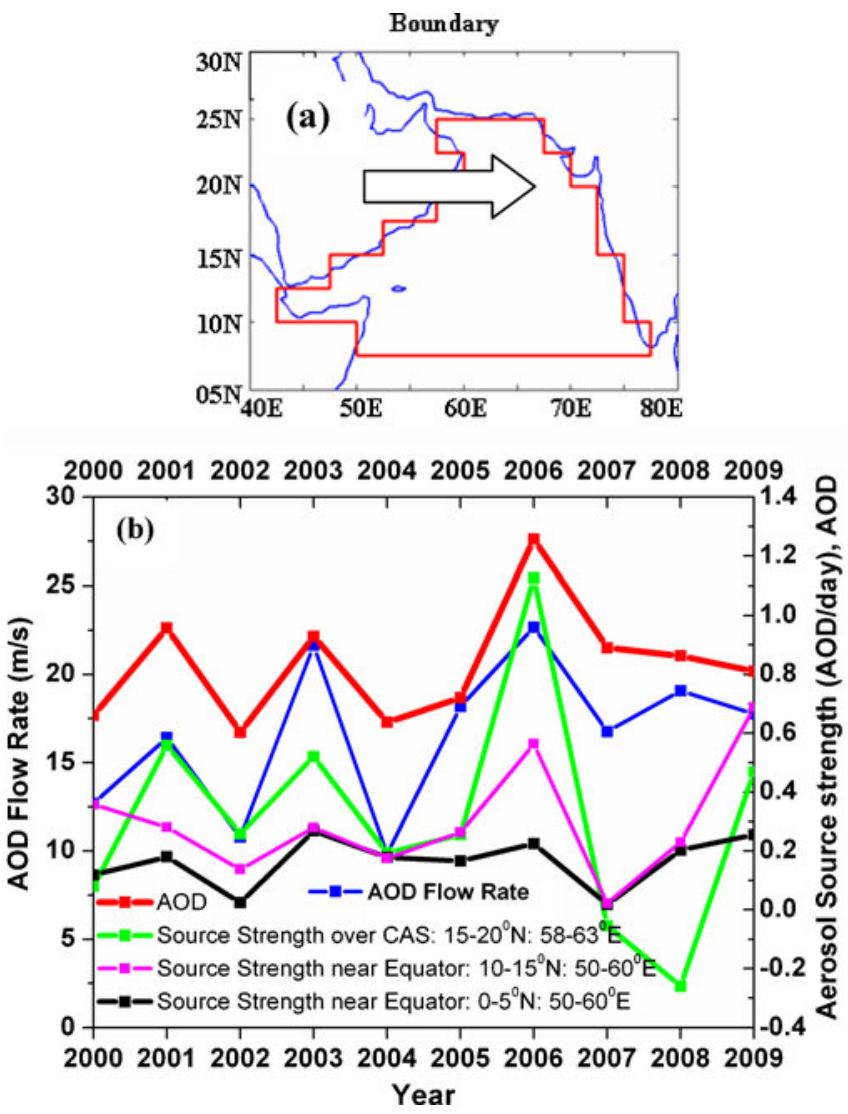

Figure 6. (a) Illustration of the boundary selected for the AOD flow rate estimation and (b) variation of AOD, source strength and AOD flow rate over the Arabian Sea for the month of July during the period 2000-2009.

zonal and meridional components of wind are available at standard pressure levels (i.e., 1000, 925, $850 \mathrm{hPa}$ ) and then multiplied with corresponding wind at these levels. The AFR into the region is considered as positive and that out from the region is negative.

Figure 6(b) shows the AOD, source strength and AFR over the Arabian Sea during the month of July for the period 2000-2009. The left Y-axis shows the variation of AFR and right axis gives the variation of both AOD and source strength. Here the source strength is estimated over coastal Arabia $\left(15^{\circ}-20^{\circ} \mathrm{N} ; 58^{\circ}-63^{\circ} \mathrm{E}\right)$ and over the locations south of Arabian Sea $\left(0-5^{\circ} \mathrm{N} ; 50^{\circ}-60^{\circ} \mathrm{E}\right)$ and $\left(10^{\circ}-\right.$ $\left.15^{\circ} \mathrm{N} ; 50^{\circ}-60^{\circ} \mathrm{E}\right)$. The source strength is the representative of net aerosol production over the region and it varies from positive to negative values which indicate the relative dominance of aerosol generation and loss mechanisms. It can be seen that, a clear biennial variability is observed in source strength over coastal Arabia. Moreover, source strength during 2008 shows negative values representing aerosol loss. In addition to this, an attempt was made to examine the aerosol source strength over a region near equator, in the southwestern
Arabian Sea $\left(0-5^{\circ} \mathrm{N} ; 50^{\circ}-60^{\circ} \mathrm{E}\right)$ and $\left(10^{\circ}-15^{\circ} \mathrm{N}\right.$; $\left.50^{\circ}-60^{\circ} \mathrm{E}\right)$ which is represented as a black curve in figure $6(\mathrm{~b})$. The biennial signature observed in coastal Arabia is not seen in the source strength near the equator. This is a clear indication that the source strength weakens as we move southwards in the Arabian Sea. Parameswaran et al (2008) made an attempt to separate sea-salt and non-seasalt AOD over the Indian Ocean and found that during the summer monsoon season values of seasalt AOD is less prominent at east of $65^{\circ} \mathrm{E}$. The value of sea-salt in general and the amplitude of July peak in particular are largest in the region $5^{\circ}-20^{\circ} \mathrm{N}$ and decreases towards either side. This explains the reason for the clear signatures of biennial variability observed more clearly in coastal Arabia.

The AFR indicates the aerosols transported through the desert regions of the Arabia. Both source strength and AFR show the biennial variability which are in phase with AOD during 20002007. It is important to note that even though the AFR through the western boundary of the Arabian Sea consistently reproduces the pattern of biennial variability from 2000-2009, the AOD over the Arabian Sea failed to capture the same in 2008 and 2009. However, the source strength over the Arabian Sea (sea-salt) during 2008 and 2009 is out of phase with the AFR that is in 2008 AFR is high but the source strength is low and vice-versa in 2009. The out of phase relation in source strength and AFR may be a possible explanation for the absence of biennial variability in AOD during 2008 and 2009. This shows that the observed biennial variability in AOD are due to the combined effect of biennial variability in seasalt aerosols from local production and advected dust aerosols from the desert regions of Arabia and variability in $A O D$ is predominant only when both are in same phase. Moreover the biennial variability in AOD is clearly seen in the region where the channels of dust transport $\left(15^{\circ}-25^{\circ} \mathrm{N}\right)$ and the high wind-speed coincides.

\section{Discussion}

The biennial variations in the AOD during summer months over Arabian Sea are attributed to the possible combined effects of biennial variations in in situ produced sea-salt aerosols and advected dust aerosols from the Arabian deserts. In this context, it is quite reasonable to explore its connection with other natural atmospheric biennial variabilities. One such variability is the stratospheric QBO which is characterized by alternate bands of easterly and westerly winds (Reed 1961). The period over which the alternate wind regimes 
repeat vary from 22 to 34 months, with an average period of $\sim 28$ months (Baldwin et al 2001). The effect of QBO is not only confined to atmospheric dynamics but also on trace constituents such as ozone, water vapour, methane, $\mathrm{NO}_{2}, \mathrm{HF}, \mathrm{HCl}$ and volcanic aerosols (Jones et al 1998; Dunkerton 2001; Fleming et al 2002; Yuejuan et al 2005). Kane (1992) reported periodicities in the concentration of trace elements and surface aerosols in the range of $2-3$ years $(\mathrm{QBO})$ and $3-5$ years (quasitriennial oscillations, QTO). Beegum et al (2009) show discernible signatures of QBO in the monthly mean AOD, particularly at equatorial locations over Asia and Africa. They have reported that the QBO observed in AOD were out of phase with the stratospheric $\mathrm{QBO}$ at the equatorial stations and in phase at the off-equatorial and subtropical stations. It was also pointed out that the stratospheric QBO induces a meridional circulation with equatorial convection (subsidence) during its east (west) phase, and off-equatorial subsidence (convection), with a cooler (warmer) and higher (lower) tropopause at the equatorial (offequatorial) regions and the associated vertical as well as horizontal mixing of mass flux modulates the AOD. In the present study, we explore the biennial variations in the summer peak in AOD over Arabian Sea, which is more or less a flipflop mechanism rather than an oscillation. The Tropospheric Biennial Oscillations (TBO), which is defined as the tendency for a relatively strong monsoon to be followed by a relatively weak one, and vice versa, with the transitions occurring in the season prior to the monsoon involving coupled land-atmosphere-ocean processes over a large area of the Indo-Pacific region (Meehl 1997; Meehl and Arblaster 2001, 2002a, 2002b), also tends to flipflop back and forth from year to year and may have influence in the biennial variability observed in the AOD over Arabian Sea. Recent studies show link between TBO and the stratospheric QBO over the monsoon region $\left[10^{\circ}-30^{\circ} \mathrm{N} ; 65^{\circ}-\right.$ $\left.95^{\circ} \mathrm{E}\right]$ through the monsoon low-level jet observed in the lower troposphere (Mohankumar and Pillai 2008). Westerly anomalies in the lower stratosphere are transferred to the lower troposphere and activated low level monsoonal circulation. Previous investigations on the aerosol distributions over the Arabian Sea have revealed the significant role of dust transport from the Arabia through the combined effect of the westerly wind over the Arabian region and the intense low-level jet over the Arabian Sea (Nair et al 2005b). Hence, any modulation in the low-level jet by TBO for instance, can introduce periodicities in the observed aerosol distribution. Another relevant observation is the influence of TBO in the mean meridional circulation and local Hadley circulation (Pillai and Mohankumar 2008). The mean meridional circulation exhibits the TBO cycle in the weak-to-strong phase of the monsoon for ENSO-TBO years, but is absent in the next strong-to-weak cycle. In ENSO-TBO years, upward (downward) motion exists in the entire NH tropics during a strong (weak) monsoon. In the case of normal TBO years, this upward (downward) anomaly during a strong (weak) monsoon is seen over the Indian monsoon area only and the opposite anomaly is seen over the equatorial region. They also found that this local Hadley circulation pattern is in agreement with the convection pattern over the maritime continent and Equatorial Indian Ocean. It is already seen that the variabilities in the circulation and convection can modulate AOD over the region. In this context, we conjecture that, the observed variability in AOD could be associated with the biennial oscillation in lower tropospheric circulation, the TBO related to monsoon dynamics, which in turn may be influenced by the stratospheric QBO as well.

\section{Conclusion}

An analysis of inter-annual variation of AOD over the Arabian Sea during 1996-2009, derived from NOAA-AVHRR and MODIS satellite data indicated systematic biennial variations. These were significant and conspicuous over the central and northern Arabian Sea, due north of $15^{\circ} \mathrm{N}$, were rather weak in the southern longitudes. They were also highly associated with lower tropospheric wind speed. An analysis of the associated periodicities as well as the source strengths over different regions of the Arabian Sea showed that the biennial oscillations in AOD over the central and northern Arabian Sea are attributed to the combined effects of wind-generated sea-salt aerosols and aerosols picked up from the Arabian and African deserts (again by winds) as demonstrated by the close association with the biennial oscillations in lower tropospheric circulation (probable TBO related monsoon dynamics) and with the stratospheric QBO.

\section{Acknowledgements}

The authors acknowledge NASA for providing MODIS aerosol data. The AVHRR data is obtained from the NOAA Satellite Active Archive. The NCEP/NCAR reanalysis is provided by the NOAA-CIRES Climate Diagnostics Center, Boulder Colorado from their website at http://www.cdc.noaa.gov. They also thank the anonymous reviewers for several useful comments. 


\section{References}

Aloysius M, Mohan M, Parameswaran K, George S K and Nair P R 2008 Aerosol transport over the Gangetic basin during ISRO-GBP land campaign-II; Ann. Geophys. 26 431-440.

Andreae M O, Rosenfeld D, Artaxo P, Costa A A, Frank G P, Longo K M and Silva-Dias M A F 2004 Smoking rain clouds over the Amazon; Science 303(5662) 1337-1342.

Babu S S, Nair V S and Moorthy K K 2008 Seasonal changes in aerosol characteristics over Arabian Sea and their consequence on aerosol shortwave radiative forcing: Results from ARMEX field campaign; J. Atmos. Sol. Terr. Phys. 70(5) 820-834, doi: 10.1016/j.jastp.2007.10.005.

Baldwin M P, Gray L J, Dunkerton T J, Hamilton K, Haynes P H, Randel W J, Holton J R, Alexander M J, Hirota I, Horinouchi T, Jones D B, Kinnersley J S, Marquardt C, Sato K and Takahashi M 2001 The quasi-biennial oscillation; Rev. Geophys. 39 179-230.

Beegum N S, Moorthy K K, Babu S S, Reddy R R, Gopal K R and Ahmed Y N 2009 Quasi-biennial oscillations in spectral aerosol optical depth; Atmos. Sci. Lett. 10 279-284.

Chapman E G, Shaw W J, Easter R C, Bian X and Ghan S J 2002 Influence of wind speed averaging on estimates of di-methyl sulfide emission fluxes; J. Geophys. Res. 107(D23) 4672, doi: 10.1029/ 2001JD001564.

Charlson R J, Schwartz S E, Hales J M, Cess R D, Coakley J A, Hansen J E and Hofmann D J 1992 Climate forcing by anthropogenic aerosols; Science 255 423-430.

Dunkerton T J 2001 Quasi-biennial and sub-biennial variations of stratospheric trace constituents derived from HALOE observations; J. Atmos. Sci. 58 7-25.

Fleming E L, Jackman C H, Rosenfield J E and Considine D B 2002 Two dimensional model simulations of the QBO in ozone and tracers in the tropical stratosphere; J. Geophys. Res. 107(D23) 4665.

Gogoi M M, Moorthy K K, Babu S S and Bhuyan P K 2009 Climatology of columnar aerosol properties and the influence of synoptic conditions: First-time results from the northeastern region of India; J. Geophys. Res. 114 D08202, doi: 10.1029/2008JD010765.

Husar R B, Prospero J M and Stowe L L 1997 Characterization of tropospheric aerosols over the ocean with the NOAA AVHRR optical thickness operational product; J. Geophys. Res. 102 16,889-16,909.

IPCC 2007 Climate Change 2007 The physical science basis, In: Contribution of Working Group I to the Fourth Assessment Report of the Intergovernmental Panel on Climate Change, Cambridge Univ. Press, New York, 996p.

Jones D B A, Schneider H R and McElroy M B 1998 Effect of the quasi-biennial oscillation on the zonally averaged transport of tracers; J. Geophys. Res. 103 11,235-11,249.

Kalnay E, Kanamitsu M, Kistler R, Collins W, Deaven D, Gandin L, Iredell M, Saha S, White G, Woollen J, Zhu Y, Chelliah M, Ebisuzaki W, Higgins W, Janowiakb J, Mo K C, Ropelewski C, Wang J, Leetmaa A, Reynolds R, Jenne R and Joseph D 1996 The NCEP/NCAR Reanalysis 40-year Project; Bull. Am. Meteorol. Soc. 77 437-471.

Kane R P 1992 Relationship between QBOs of stratospheric winds, ENSO variability and other atmospheric parameters; Int. J. Climatol. 12 435-447.

Kaufman Y J and Koren I 2006 Smoke and pollution aerosol effect on cloud cover; Science 313(5787) 655-658.

Levy R C, Remer L A, Martins J V, Kaufman Y J, PlanaFattori A, Redemann J and Wenny B 2005 Evaluation of the MODIS aerosol retrievals over ocean and land during CLAMS; J. Atmos. Sci. 62(4) 974-992.
Levy R C, Remer L A, Tanre D, Kaufman Y J, Ichoku C, Holben B N, Livingston J M, Russell P B and Maring H 2003 Evaluation of the Moderate Resolution Imaging Spectro-radiometer (MODIS) retrievals of dust aerosol over the ocean during PRIDE; J. Geophys. Res. 108(D19) 8594, doi: 10.1029/2002JD002460.

Martins J V, Tanre D, Remer L, Kaufman Y, Mattoo S and Levy R 2002 MODIS cloud screening for remote sensing of aerosols over oceans using spatial variability; Geophys. Res. Lett. 29(12) 1619, doi: 10.1029/ 2001GL013252.

Meehl G A 1997 The South Asian monsoon and the tropospheric biennial oscillation; J. Climate 10 1921-1943.

Meehl G A and Arblaster J M 2001 The tropospheric biennial oscillation and Indian monsoon rainfall; Geophys. Res. Lett. 28 1731-1734.

Meehl G A and Arblaster J M 2002a The tropospheric biennial oscillation and Asian-Australian monsoon rainfall; J. Climate 15 722-744.

Meehl G A and Arblaster J M 2002b GCM sensitivity experiments for the Indian monsoon and tropospheric biennial oscillation transition conditions; J. Climate 15 923-944.

Mohankumar K and Pillai P A 2008 Stratospheretroposphere interaction associated with biennial oscillation of Indian summer monsoon; J. Atmos. Sol. Terr. Phys. 70 764-773.

Moorthy K K, Satheesh S K and Murthy B V K 1997 Investigations of marine aerosols over the tropical Indian Ocean; J. Geophys. Res. 102 18,827-18,842.

Moorthy K K and Satheesh S K 2000 Characteristics of aerosols over a remote island Minicoy in Arabian Sea: Optical properties and retrieved size characteristics; Quart. J. Roy. Meteorol. Soc. 126 81-109.

Moorthy K K, Sunilkumar S V, Pillai P S, Parameswaran K, Nair P R, Ahmed Y N, Ramgopal K, Narasimhulu K, Reddy R R, Vinoj V, Satheesh S K, Niranhan K, Rao B M, Brahmanandam P S, Saha A, Badarinath K V S, Kiranchand T R and Latha K M 2005 Winter time spatial characteristics of boundary layer aerosols over peninsular India; J. Geophys. Res. 110 D08207, doi: 10.1029/2004JD005520.

Moorthy K K, Babu S S and Satheesh S K 2007 Temporal heterogeneity in aerosol characteristics and the resulting radiative impact at a tropical coastal station - part 1: microphysical and optical properties; Ann. Geophys. 25 2293-2308.

Nair P R, Parameswaran K, Annamma A and Salu J 2005a Wind dependence of sea-salt and non-sea-salt aerosols over the oceanic environment; J. Atmos. Sol. Terr. Phys. 67 844-898, doi: 10 1016/j-jastp.

Nair S K, Parameswaran K and Rajeev K 2005b Seven-year satellite observations of the mean structures and variabilities in the regional aerosol distribution over the oceanic areas around the Indian subcontinent; Ann. Geophys. 23 2011-2030.

Nair S K, Rajeev K and Parameswaran K 2003 Winter time regional aerosol distribution and the influence of continental transport over the Indian Ocean; J. Atmos. Sol. Terr. Phys. 65 149-165.

Parameswaran K, Nair S K and Rajeev K 2008 Impact of aerosols from the Asian continent on the adjoining oceanic environments; J. Earth Syst. Sci. 17 83-102.

Pillai P A and Mohankumar K 2008 Local Hadley circulation over the Asian monsoon region associated with the Tropospheric Biennial Oscillation; Theor. Appl. Climatol. 91(1-4) 171-179, doi: 10.1007/s00704-007-0305-5.

Rajeev K and Ramanathan V 2001 Direct observations of clear-sky aerosol radiative forcing from space during the Indian Ocean Experiment; J. Geophys. Res. 106 $17,221-17,236$. 
Rajeev K, Ramanathan V and Meywerk J 2000 Regional aerosol distribution and its long-range transport over the Indian Ocean; J. Geophys. Res. 105 2029-2043.

Ramanathan V, Crutzen P J, Kiehl J T and Rosenfeld D 2001 Aerosols, climate and the hydrological cycle; Science $2942119-2124$.

Reed R J 1961 Evidence of the downward propagating wind reversal in the equatorial stratosphere; J. Geophys. Res. 66 813-818.

Remer L A, Tanré D, Kaufman Y J, Ichoku C, Mattoo S, Levy R, Chu D A, Holben B N, Martins J V, Li R R and Ahmad Z 2002 Validation of MODIS aerosol retrieval over ocean; Geophys. Res. Lett. 29(12) 1-4.

Remer L A, Kaufman Y J, Tanré D, Mattoo S, Chu D A, Martins J V, Li R R, Ichoku C, Levy R C, Kleidman R G, Eck T F, Vermote E and Holben B N 2005 The MODIS aerosol algorithm, products and validation; J. Atmos. Sci. Spec. Issue 62 947-973.

Rosenfeld D 1999 TRMM observed first direct evidence of smoke from forest fires inhibiting rainfall; Geophys. Res. Lett. 26(20) 3105-3108.

Rosenfeld D 2000 Suppression of rain and snow by urban and industrial air pollution; Science 287(5459) 1793-1796.

Saha A, Moorthy K K and Niranjan K 2005 Inter-annual variations of aerosol optical depth over coastal India: Relation to synoptic meteorology; J. Appl. Meteor. 44 1066-1077.

Satheesh S K and Ramanathan V 2000 Large differences in tropical aerosol forcing at the top of the atmosphere and Earth's surface; Nature 405(6782) 60-63.

Satheesh S K and Srinivasan J 2002 Enhanced aerosol loading over Arabian Sea during the pre-monsoon season: Natural or anthropogenic? Geophys. Res. Lett. 29 1874, doi: 10.1029/2002GL015687.
Satheesh S K and Moorthy K K 1997 Aerosol characteristics over coastal regions of the Arabian Sea; Tellus 49B 417-428.

Satheesh S K, Ramanathan V, Holben B N, Moorthy K K, Loeb N G, Maring H, Prospero J M and Savoie D 2002 Chemical, microphysical, and radiative effects of Indian Ocean aerosols; J. Geophys. Res. 107(D23) 4725, doi: 10.1029/2002JD002463.

Satheesh S K, Srinivasan J and Moorthy K K 2006 Contribution of sea salt to aerosol 665 optical depth over the Arabian Sea derived from MODIS observations; Geophys. Res. Lett. 33 L03809, doi: 10.1029/ 2005 GL024856.

Smirnov A B, Holben N, Eck T F, Dubovik O and Slutsker I 2000 Cloud-screening and quality control algorithms for the AERONET database; Remote Sens. Environ. 73(3) $337-349$.

Torrence C and Compo G P 1998 A practical guide to wavelet analysis; Bull. Am. Meteorol. Soc. 79 61-78.

Twomey S A, Piepgrass M and Wolfe T L 1984 An assessment of the impact of pollution on global cloud albedo; Tellus 36(5) 356-366.

Vinoj V and Satheesh S K 2003 Measurements of aerosol optical depth over Arabian Sea during summer monsoon season; Geophys. Res. Lett. 30(5) 1263, doi: 10.1029/2002GL016664.

Yuejuan C, Chunhua S and Bin Z 2005 HCL Quasi-biennial oscillation in the stratosphere and a comparison with ozone QBO; Adv. Atmos. Sci. 22(5) 751-758.

Zhu A, Ramanathan V, Li F and Kim D 2007 Dust plumes over the Pacific, Indian, and Atlantic oceans: Climatology and radiative impact; J. Geophys. Res. 112(D16208) 15, doi: 10.1029/2007JD008427. 